\title{
IMPACT OF INTEROPERABILITY OF INFORMATION SYSTEMS - THE CASE OF INSTITUTIONS OF THE REPUBLIC OF KOSOVO
}

\author{
Kujtim Gashi \\ University of Tirana, Economy Faculty, Department of Statistics and Applied Informatics, Tirana, Albania; \\ Corresponding author Kujtim Gashi, e-mail: gashi.kujtim@outlook.com;
}

Received October, 2018; Accepted November, 2018; Published January, 2019;

DOI: https://doi.org/10.31407/ijees9108

UOI license: http://u-o-i.org/1.01/ijees/82995744

\begin{abstract}
Interoperability of information systems as a conpcept witihin governmental institutions has been used by different governmental institutions around the World. Therefore, the main purpose of this was to identify the state and level of realization of interoperability of electronic systems by institutions of the Republic of Kosovo, with a deeper focus on creation of governmental gateway as an interface of e-services hub in a national level. Initially, academic literature was used to understand the importance of the most successful governance methods including eGovernance and rational management as well as to analyze the use of various e-services and interaction between them. Also, this paper is based on case study approach that the author has had the opportunity to directly interact during the implementation and management teams, which was used as the main research methodology and data collection.
\end{abstract}

Keywords: Information Systems, e-Government, Interoperability, Governmental Gateway 